\title{
PENGARUH PENAMBAHAN POTONGAN LIMBAH BANNER DENGAN BENTUK POTONGAN MEMANJANG TERHADAP KUAT TEKAN DAN KUAT LENTUR BETON
}

\section{Rista Novita Catur Putri ${ }^{1}$, Anis Rahmawati ${ }^{2}$, Ida Nugroho Saputro ${ }^{2}$ Pendidikan Teknik Bangunan, Universitas Sebelas Maret email: rista0524@gmail.com}

\begin{abstract}
Abstrak: Tujuan dari penelitian ini untuk mengetahui: (1) pengaruh penambahan potongan limbah banner terhadap berat jenis beton; (2) pengaruh penambahan potongan limbah banner terhadap kuat tekan beton; (3) pengaruh penambahan potongan limbah banner terhadap kuat lentur beton; (4) persentase penambahan limbah banner optimum pada kuat tekan dan kuat lentur beton maksimum. Penelitian ini merupakan penelitian kuantitatif dengan menggunakan metode eksperimen. Perencanaan pembuatan campuran beton menggunakan metode mix design sesuai dengan SNI 03-3449-2002. Variasi persentase penambahan banner yang digunakan adalah $0,00 \%, 0,20 \%, 0,40 \%, 0,60 \%, 0,80 \%$ dan $1,00 \%$ dengan mutu beton yang direncanakan yaitu fc' $20 \mathrm{MPa}$. Karakteristik beton yang diuji dalam penelitian ini adalah berat jenis, kuat tekan dan kuat lentur beton pada usia 28 hari. Benda uji untuk pengujian berat jenis dan kuat tekan berbentuk silinder dengan diameter $150 \mathrm{~mm}$ dan tinggi $300 \mathrm{~mm}$. Benda uji untuk pengujian lentur berbentuk balok dengan dimensi 150 × 150 × $600 \mathrm{~mm}$. Hasil pengujian terhadap beton yang telah mengeras yaitu pada usia setelah 28 hari dengan penambahan potongan limbah banner optimum tekan terdapat pada variasi $0,20 \%$ dengan kuat tekan 21,967 $\mathrm{MPa}$ dan optimum lentur terdapat pada variasi 0,40\% dengan kuat lentur 4,663 MPa. Hasil pengujian berat jenis dari seluruh variasi termasuk dalam beton normal. Simpulan dari penelitian ini adalah terdapat pengaruh penambahan potongan limbah banner terhadap berat jenis beton yaitu semakin besar persentase penambahan semakin kecil nilai berat jenis beton. Penambahan potongan limbah banner berpengaruh negatif terhadap kuat tekan dan kuat lentur beton.
\end{abstract}

Kata Kunci: bahan tambah, beton, banner, berat jenis, kuat tekan, kuat lentur.

\footnotetext{
${ }^{1}$ Mahasiswa Program Studi Pendidikan Teknik Bangunan FKIP UNS.

${ }^{2}$ Pembimbing I Anis Rahmawati, S.T., M.T.

${ }^{3}$ Pembimbing II Ida Nugroho Saputro, S.T., M.Eng.
} 


\title{
EFFECT OF ADDITION WASTE CUTTING BANNER WITH LONGITUDINAL SHAPE TO THE COMPRESSION STRENGTH AND BENDING STRENGTH OF CONCRETE.
}

\author{
Rista Novita Catur Putri ${ }^{1}$, Anis Rahmawati ${ }^{2}$, Ida Nugroho Saputro ${ }^{2}$ \\ Pendidikan Teknik Bangunan, Universitas Sebelas Maret \\ email: rista0524@gmail.com
}

\begin{abstract}
Abstrack: The purposes of this research were to know: (1) influence of additional waste cutting banner to the specific grafity value of concrete; (2) influence of additional waste cutting banner to compression strength of concrete; (3) influence additional waste cutting banner to bending strength of concrete; (4) the optimal percentage additional waste cutting banner to had the maximum value of compression strength and bending strength of concrete. This was a quantitative research using experiment method. The planned of concrete using mix design method suitable with SNI 03-3449-2002. Variation in percentage used was 0,00\%, 0,20\%, 0,40\%, 0,60\%,0,80\% and 1,00\% with $f_{c}$ ' planned $20 \mathrm{MPa}$. The concretes characteristics tested in this research were specific grafity, compression strength and bending strength on 28 day of concrete age. The shape of specimen for specific grafity test and compression strength test was a cylinder with $15 \mathrm{~mm}$ for diameter and $300 \mathrm{~mm}$ for the height. The shape of specimen for bending strength test was a rectangular prism with dimension $150 \mathrm{~mm}$ for hight, $150 \mathrm{~mm}$ for width and $600 \mathrm{~mm}$ for lenght. The test result of concrete after 28 days with additional waste banner optimum in variation 0,20\% on compression strength test which read 21,967 MPa and optimum variation $0,40 \%$ on bending strength test which read 4,663 MPa. The result of specific grafity test in all variation was normal concrete on specific grafity. The conclusion of the research were the addition waste of the banner does influence specific grafity test, the greater percentage additional of banner smaller value of the concrete specific grafity. The addition waste of banner does negative influence of compression strength and bending strength of concrete.
\end{abstract}

Key Words: additional, concrete, banner, specific grafity, compression strength, bending strength.

\footnotetext{
${ }^{1}$ Mahasiswa Program Studi Pendidikan Teknik Bangunan FKIP UNS.

${ }^{2}$ Pembimbing I Anis Rahmawati, S.T., M.T.

${ }^{3}$ Pembimbing II Ida Nugroho Saputro, S.T., M.Eng.
} 


\section{PENDAHULUAN}

Laju pertumbuhan penduduk meningkat pesat dari tahun-ketahun. Berdasarkan data yang diterbitkan oleh Badan Pusat Statistik (bps.go.id), laju pertumbuhan penduduk di Indonesia berada diangka $1,49 \%$ pada tahun 2000-2010. Pertumbuhan penduduk yang terjadi berpengaruh terhadap kebutuhan manusia akan struktur bangunan. Hal ini mengharuskan manusia untuk memenuhi tuntutan kebutuhan stuktur. Pertumbuhan yang ada harus dibarengi perkembangan akan teknologi beton sebagai upaya memenuhi kebutuhan struktur yang terus meningkat.

\section{Sampah atau limbah} merupakan masalah yang belum dapat diselesaikan secara konkret. Berbagai upaya yang dilakukan pemerintah belum juga menunjukkan hasil yang maksimal. Hal ini terlihat dari buruknya sistem pengelolaan sampah yang ada dimasyarakat. Sehingga masalah sampah atau limbah harus segera diselesaikan. Sampah atau limbah tidak hanya menyebabkan pencemaran pada tanah, tetapi juga pencemaran air dan udara. Salah satu contoh sampah yang sulit didaur ulang adalah banner bekas periklanan atau advertisement, berupa spanduk yang terbuat dari bahan mirip plastik. Sampah ini, ikut menyumbang tingkat percemaran yang ada. Menurut Winardi (1992: 112) "Para individu dan organisasi-organisasi menggunakan pengiklanan untuk tujuan promosi barang-barang, jasajasa, ide-ide, issue-issue dan orangorang sebagai kandidat politikal. Oleh karena itu pemasangan banner sebagai usaha periklanan dinilai efektif dalam usaha menarik perhatian konsumen".

Pemanfaatan sampah bekas advertisement yang telah dilakukan dinilai kurang efisien karena hanya dimanfaatkan sebagai alas duduk. Banner sebagai bahan baku advertisment terbuat dari campuran nylon dan polivinyl, limbah ini digolongkan sebagai limbah anorganik yang sulit untuk diuraikan. Menurut Pine, dkk (1988: 1043) "Polivinyl adalah polimer yang terbentuk akibat 
aksi ikat-mengikat dengan ciri kuat dan keras. Sedangkan nylon merupakan poliamida buatan yang mempunyai gaya regang yang baik sekali bila dijadikan serat". Untuk dapat memanfaatkan limbah banner maka perlu dilakukan penelitian guna menunjang nilai fungsional dari limbah banner tersebut.

Beton merupakan bahan utama yang digunakan dalam bidang konstruksi pada saat ini. Beton dipilih sebagai bahan bangunan karena mempunyai kuat tekan yang tinggi. Secara struktural beton mempunyai tegangan tekan yang besar, sehingga bermanfaat untuk menahan gaya-gaya tekan. Akan tetapi, beton memiliki kelemahan yaitu kekuatan tariknya sangat rendah, bersifat getas, dan sering terjadi retakan-retakan pada beton yang telah mengeras. Sering dijumpai pada balok, terdapat retak memanjang dan retak halus yang disebabkan oleh gaya tarik yang bekerja pada beton. Semakin lama retak-retak halus yang ada akan semakin memanjang dan mengurangi kekuatan dari beton. Sehingga perlu dilakukan penambahan tulangan pada beton untuk menahan gaya tarik yang ada.

Selain dilakukan penambahan tulangan pada beton, untuk memperbaiki sifat beton yang rentan terhadap tarik dan retakan serta bersifat getas dilakukan penambahan bahan tambah pada campuran beton. Bahan tambah ialah suatu bahan berupa bubuk, serat, atau cairan yang ditambahkan kedalam campuran adukan beton selama proses pengadukan. Salah satu bahan tambah yang dapat digunakan pada beton adalah serat (fibre). Campuran antara beton dan bahan serupa serat disebut dengan beton serat atau fibre concrete. Maksud utama dilakukan penambahan serat pada beton adalah untuk menambah kuat tarik, menambah daktalitas, dan menambah ketahanan terhadap retak. Sehingga didapat beton dengan sifat atau karakteristik yang lebih baik. 
Penelitian ini memanfaatkan

limbah banner sebagai limbah yang sulit untuk didaur ulang guna meningkatkan kinerja beton serat dalam rangka memenuhi kebutuhan masyarakat akan struktur bangunan. Penelitian ini dilakukan untuk mendapatkan bahan alternatif baru dalam teknologi beton, dengan menggunakan potongan banner yang digunakan sebagai serat dalam pembuatan beton. Karena banner yang ada belum dimanfaatkan dan belum dieksplorasi pemanfaatannya oleh masyarakat sebagai campuran adukan beton.

Oleh karena itu tujuan dari penelitian ini adalah untuk mengetahui karakteristik beton dengan penambahan potongan limbah banner, mengetahui nilai berat jenis, kuat tekan, dan kuat lentur beton dengan penambahan potongan limbah banner, serta mengetahui nilai optimum penambahan untuk menghasilkan kuat tekan dan kuat lentur maksimum beton.

\section{METODE PENELITIAN}

Penelitian dilaksanakan di Laboratorium Program Studi Pendidikan Teknik Bangunan Universitas Sebelas Maret Surakarta pada bulan Desember 2015 - Juli 2016. Limbah banner yang digunakan didapat dari limbah sekitar kampus yang sudah tidak digunakan, selanjutnya dipotong dengan ukuran panjang $25 \mathrm{~mm}$ - $100 \mathrm{~mm}$ dengan lebar $5 \mathrm{~mm}$.

Jenis penelitian yang digunakan adalah penelitian kuantitatif yaitu mengambil suatu gambaran mengenai pengaruh penambahan potongan limbah banner dengan bentuk potongan memanjang terhadap kuat tekan dan kuat lentur beton dengan penggunakan metode mix design pada proses pembuatan adukan. Fc' yang direncanakan adalah $20 \mathrm{MPa}$.

Sampel yang digunakan yaitu benda uji berbentuk silinder dengan diameter $150 \mathrm{~mm}$, tinggi $300 \mathrm{~mm}$ untuk pengujian tekan dan pengujian berat jenis. Benda uji berbentuk balok 
dengan panjang sisi $150 \mathrm{~mm} \times 150$ mm x $600 \mathrm{~mm}$ untuk pengujian kuat lentur. Pada tabel berikut akan dijelaskan banyaknya sampel dalam satu varian. Dimana seluruh sampel yang ada merupakan anggota dari populasi.

Tabel 1. Jumlah Sampel



\section{Berat Jenis}

Pengujian berat jenis sesuai dengan SK 03-2834-1992 dengan menimbang dan mengukur dimensi benda uji silinder yang digunakan. Persamaan yang digunakan untuk menghitung berat jenis beton adalah:

$\rho=\frac{\mathrm{m}}{\mathrm{v}}$

Dimana:

$\rho \quad=$ Berat jenis beton $\left(\mathrm{Kg} / \mathrm{m}^{3}\right)$

$\mathrm{m}=$ Berat beton $(\mathrm{Kg})$

$\mathrm{v} \quad=$ Volume Beton $\left(\mathrm{m}^{3}\right)$

\section{Kuat Tekan}

Pengujian kuat tekan dilaksanakan sesuai dengan SNI 031972-1990 dengan menggunakan Compression Testing Machine (CTM) dengan menekan benda uji. Persamaan yang digunakan adalah:

$\mathrm{Fc}^{\prime}=\frac{\mathrm{P}}{\mathrm{A}}$

Dimana:

$\mathrm{Fc}^{\prime}=$ Kuat tekan beton $\left(\mathrm{N} / \mathrm{mm}^{2}\right)$

$\mathrm{P}=$ Beban maksimal tekan $(\mathrm{N})$

$\mathrm{A}=$ Luas penampang tekan $\left(\mathrm{mm}^{2}\right)$ 

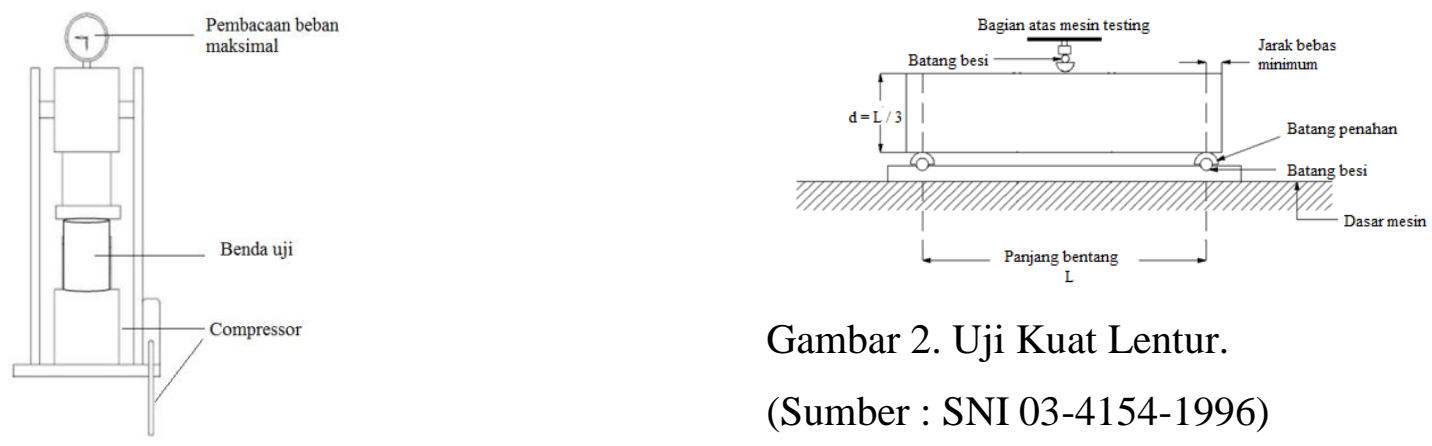

Gambar 2. Uji Kuat Lentur.

(Sumber : SNI 03-4154-1996)

Gambar 1. Uji Kuat Tekan.

(Sumber: Nugraha dan Antoni, 2007:262)

\section{Kuat Lentur}

Pengujian kuat lentur dilaksanakan sesuai dengan SNI 034154-1996 menggunakan Universal Testing Machine (UTM) dengan pembebanan satu titik. Persamaan yang digunakan adalah:

$\mathrm{Fl}=\frac{3 \mathrm{PL}}{2 \mathrm{bd}^{2}}$

Dimana:

Fl = Kuat lentur beton $\left(\mathrm{N} / \mathrm{mm}^{2}\right)$

$\mathrm{P}=$ Beban maksimum $(\mathrm{N})$

$\mathrm{L}=$ Jarak antar tumpuan (mm)

$\mathrm{b} \quad=$ Lebar penampang $(\mathrm{mm})$

$\mathrm{d} \quad=$ Tinggi penampang $(\mathrm{mm})$ 
kesimpulan hasil penelitian yang telah dilakukan.

\section{HASIL PENELITIAN DAN PEMBAHASAN}

\section{Hasil Penelitian}

Metode mix design digunakan sebagai acuan dalam perencanaan pembuatan adukan beton. Nilai Fc' yang direncanakan adalah $20 \mathrm{MPa}$. Selanjutnya dilakukan pengujian terhadap agregat kasar dan agregat halus untuk mengetahui karakteristik bahan adukan dan untuk mengetahui proporsi masing-masing bahan penyusun yang digunakan. Berikut merupakan hasil pengujian yang telah dilakukan:

Tabel 2. Pengujian Agregat Halus.

\begin{tabular}{lc}
\hline \multicolumn{1}{c}{ Parameter } & Hasil \\
\hline Kandungan Lumpur & $0,6 \%$ \\
Zat Organik & Kuning Muda \\
Bulk Spesific Gravity & 2.56 \\
Absorbsi & $1,02 \%$ \\
Modulus Kehalusan & 3,25 \\
Kadar Air & $0,0033 \%$
\end{tabular}


Tabel 3. Pengujian Agregat Kasar.

\begin{tabular}{cc}
\hline Parameter & Hasil \\
\hline Modulus Kehalusan & 3,28 \\
Abrasi Agregat Kasar & $46,47 \%$ \\
Bulk Specific Gravity & 2,41 \\
\hline
\end{tabular}

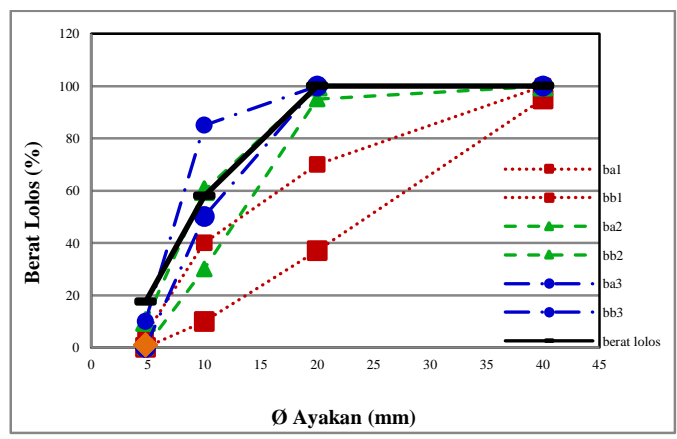

Gambar 4. Pengujian Gradasi Agregat Kasar.

Berdasarkan hasil pengujian gradasi agregat kasar berdasarkan gambar 4 dan tabel 3, agregat kasar memiliki gradasi yang baik yaitu berada pada batas daerah gradasi agregat kasar dengan diameter $10 \mathrm{~mm}$. Hal ini memenuhi persyaratan yang ada yaitu besar maksimal agregat kasar yang digunakan adalah $<20 \mathrm{~mm}$. Berdasarkan hasil pengujian agregat kasar yaitu pengujian abrasi memenuhi standar yang ada dan modulus kehalusan tidak memenuhi standar. Sedangkan menurut hasil pengujian bulk specific gravity (SSD), berat jenis agregat kasar rendah. Sehingga beton yang dihasilkan akan lebih ringan. Berdasarkan seluruh hasil pengujian agregat kasar yang telah dilaksanakan, maka dapat ditarik kesimpulan bahwa agregat dapat digunakan pada adukan beton. Beton yang dihasilkan akan mengikuti karakteristik bahan penyusunnya termasuk agregat kasar.

Bahan penyusun lain yaitu semen dilakukan pengujian secara visual yaitu terlihat tidak menggumpal. Semen yang digunakan adalah semen jenis I PPC dengan merek Gresik kemasan $40 \mathrm{~kg}$. Sedangkan air yang merupakan air yang ada digunakan berasal dari Laboratorium PTB sesuai dengan standar air minum yaitu tidak berwarna, tidak berasa, dan tidak berbau. Sedangkan serat yang digunakan adalah serat dari potongan limbah banner dengan bentuk persegi panjang. Serat memiliki ukuran panjang yaitu $25 \mathrm{~mm}-100 \mathrm{~mm}$ dengan lebar $5 \mathrm{~mm}$.

Berdasarkan hasil seluruh pengujian yang telah dilakukan maka 
dapat disimpulkan bahwa seluruh bahan penyusun beton secara umum dapat digunakan untuk membuat adukan beton. Beton yang dihasilkan memiliki karaktristik sesuai dengan karakteristik yang dimiliki oleh bahan penyusunnya. Proses pengecoran dilakukan sesuai dengan SNI 03-39761995 tentang tata cara pengadukan pengecoran beton. Selanjutnya pengujian yang dilakukan pada beton segar adalah pengujian slump. Sedangkan pengujian berat jenis, kuat tekan, dan kuat lentur dilakukan pada saat beton telah mengeras dan setelah dilakukan perawatan beton selama 28 hari.

\section{Pengujian Slump}

Pengujian yang dilakukan pada beton segar atau fresh concrete adalah pengujian slump. Pengujian slump dilakukan untuk mengetahui tingkat workability atau kemudahan beton untuk dikerjakan. Pengujian slump dilaksanakan sesuai dengan SNI 031972-1990, dengan hasil pengujian sebagai berikut:

Tabel 4. Pengujian Slump.

\begin{tabular}{cccc}
\hline & \multicolumn{3}{c}{ Nilai Slump (cm) } \\
\cline { 2 - 4 } Persentase & Silinder & Balok & $\begin{array}{c}\text { Rerata } \\
\text { Slump }\end{array}$ \\
\hline $0,00 \%$ & 12,5 & 12,5 & 12,5 \\
\hline $0,20 \%$ & 7 & 14 & 10,5 \\
\hline $0,40 \%$ & 6,5 & 10 & 8,25 \\
\hline $0,60 \%$ & 4,5 & 7,5 & 6 \\
\hline $0,80 \%$ & 4,5 & 4,5 & 4,5 \\
\hline $1,00 \%$ & 3,5 & 3 & 3,25 \\
\hline
\end{tabular}

Berdasarkan hasil pengujian slump yang telah dilakukan, nilai rerata uji slump pada persentase $0,00 \%, \quad 0,20 \%, \quad 0,40 \%$ masih memenuhi kriteria nilai slump untuk pembuatan stuktur bangunan yaitu pelat, kolom, balok, dinding. Sedangkan nilai slump pada persentase $0,60 \%, 0,80 \%, 1,00 \%$ tidak memenuhi kriteria nilai slump untuk pembuatan struktur bangunan, tetapi masih dapat digunakan untuk pembetonan masal.

\section{Pengujian Berat Jenis}

Berat jenis beton merupakan perbandiangan antara berat beton pada usia lebih dari 28 hari dibagi dengan volume beton itu sendiri. Pengujian 
berat jenis beton diperoleh dari sampel dengan bentuk silinder sebanyak 30 sampel.

Tabel 5. Pengujian Berat Jenis.

\begin{tabular}{cc}
\hline Persentase & $\begin{array}{c}\text { Berat Jenis Rata-rata } \\
\left(\mathrm{Kg} / \mathrm{m}^{3}\right)\end{array}$ \\
\hline $0,00 \%$ & 2275,26 \\
\hline $0,20 \%$ & 2284,31 \\
\hline $0,40 \%$ & 2237,77 \\
\hline $0,60 \%$ & 2250,21 \\
\hline $0,80 \%$ & 2214,65 \\
\hline $1,00 \%$ & 2205,56 \\
\hline \multicolumn{2}{c}{ Berdasarkan data hasil }
\end{tabular}

pengujian berat jenis di atas, didapat bahwa berat jenis beton dengan variasi persentase potongan banner tidak mengalami selisih yang terlalu jauh. Terjadi kenaikan rerata berat jenis beton pada persentase $0,20 \%$. Pada persentase selanjutnya mengalami penurunan dibanding dengan berat jenis beton pada persentase variasi penambahan $0 \%$. Berdasarkan nilai rerata berat jenis beton yang dihasilkan masih masuk dalam beton normal.

\section{Pengujian Kuat Tekan}

Pengujian kuat tekan beton dilakukan pada beton setelah usia 28 hari. Pengujian kuat tekan dilakukan pada 5 sampel berbentuk silinder dalam satu variasi penambahan potongan banner dengan diameter 150 $\mathrm{mm}$ dan tinggi $300 \mathrm{~mm}$ sesuai dengan SNI 03-1974-1990. Jumlah keseluruhan sampel pada pengujian kuat tekan sebanyak 30 sampel.

Tabel 6. Pengujian Kuat Tekan

\begin{tabular}{lc}
\hline Persentase & $\begin{array}{c}\text { Kuat Tekan Rata-rata } \\
\left(\mathrm{N} / \mathrm{mm}^{2}\right)\end{array}$ \\
\hline $0,00 \%$ & 20,269 \\
\hline $0,20 \%$ & 21,967 \\
\hline $0,40 \%$ & 14,879 \\
\hline $0,60 \%$ & 16,306 \\
\hline $0,80 \%$ & 11,437 \\
\hline $1,00 \%$ & 11,040 \\
\hline \multicolumn{3}{c}{ Berdasarkan rerata kuat } \\
tekan pada tabel 6, dapat diketahui \\
bahwa terjadi peningkatan rerata kuat \\
tekan beton pada persentase $0,20 \%$. \\
Selanjutnya terjadi penurunan kuat \\
tekan pada persentase $0,40 \%$. Terjadi \\
kenaikan kembali pada persentase \\
0,60\% dan terjadi penurunan kuat \\
tekan pada persentase $0,80 \%$ dan \\
1,00\%.
\end{tabular}

Pengujian Kuat Lentur 
Pengujian kuat lentur pada beton setelah usia 28 hari. Pengujian ini dilakukan pada 4 balok dalam satu variasi persentase penambahan potongan banner dengan ukuran balok $150 \mathrm{~mm} \times 150 \mathrm{~mm} \times 600 \mathrm{~mm}$ sesuai dengan ketentuan SNI 03-4154-1996 tentang metode pengujian kuat lentur beton dengan balok uji sederhana yang dibebani terpusat langsung atau dengan menggunakan satu beban terpusat. Berikut merupakan hasil pengujian kuat lentur beton:

Tabel 7. Pengujian Kuat Lentur

\begin{tabular}{cc}
\hline Persentase & $\begin{array}{c}\text { Kuat Lentur Rata-rata } \\
\left(\mathrm{N} / \mathrm{mm}^{2}\right)\end{array}$ \\
\hline $0,00 \%$ & 5,431 \\
\hline $0,20 \%$ & 4,308 \\
\hline $0,40 \%$ & 4,663 \\
\hline $0,60 \%$ & 4,421 \\
\hline $0,80 \%$ & 4,374 \\
\hline $1,00 \%$ & 4.157 \\
\hline
\end{tabular}

Berdasarkan tabel 7 , rerata kuat lentur beton yang dihasilkan memiliki grafik fluktuatif, yaitu setelah terjadi penurunan selanjutnya mengalami kenaikan dan seterusnya. Dimana berdasarkan hasil rerata kuat lentur maksimal terdapat pada persentase $0,00 \%$. Sedangkan kuat lentur terendah terdapat pada persentase $1,00 \%$.

\section{Pembahasan}

Berikut merupakan hasil pengujian berat jenis, kuat tekan, dan kuat lentur:

\section{Berat Jenis}

Berdasarkan gambar 5, terjadi kenaikan berat jenis beton pada persentase $0,20 \%$ dibanding berat jenis beton pada persentase $0,00 \%$. Pada persentase selanjutnya yaitu persentase $0,40 \%$ kembali mengalami kenaikan dibanding dengan berat jenis pada persentase sebelumnya. Pada persentase $0,60 \%$ kembali mengalami kenaikan dibanding dengan berat jenis pada persentase $0,40 \%$. Selanjutnya mengalami penurunan kembali pada persentase $0,80 \%$ dan $1,00 \%$. Nilai berat jenis tertinggi terdapat pada persentase $\quad 0,20 \%$ yaitu 2284,31 $\mathrm{kg} / \mathrm{cm}^{3}$. Sedangkan nilai berat jenis terendah berada pada persentase $1,00 \%$ yaitu $2205,56 \mathrm{~kg} / \mathrm{cm}^{3}$. 


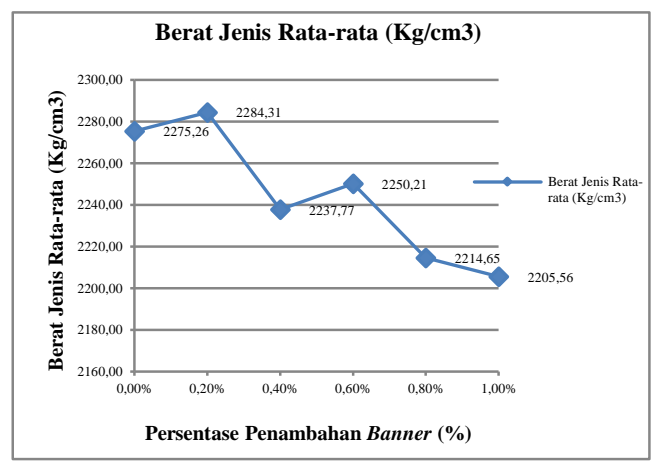

Gambar 5. Grafik Penambahan terhadap Berat Jenis Beton.

Berdasarkan nilai rerata berat jenis beton yang dihasilkan termasuk dalam beton normal. Berdasarkan grafik hasil pengujian berat jenis maka semakin besar persentase penambahan potongan limbah banner, semakin kecil berat jenis beton yang dihasilkan.

Walaupun berat jenis yang dihasilkan masuk ke dalam jenis beton normal, tetapi jika dibandingkan dengan beton dengan tanpa penambahan, berat jenis beton dengan penambahan banner memiliki berat jenis yang lebih rendah dibanding dengan berat jenis beton tanpa penambahan yang direncanakan. Hal ini terjadi karena banyaknya rongga udara yang terdapat pada beton. Karena serat yang digunakan berbentuk bidang, menyebabkan terbentuknya spesimen-spesimen yang menghalangi rekatan antar agregat sehingga terbentuklah rongga-rongga dalam beton. Oleh karena itu semakin besar persentase penambahan semakin kecil berat jenis beton yang dihasilkan.

\section{Kuat Tekan}

Berikut merupakan grafik dan diagram batang hasil pengujian kuat tekan:

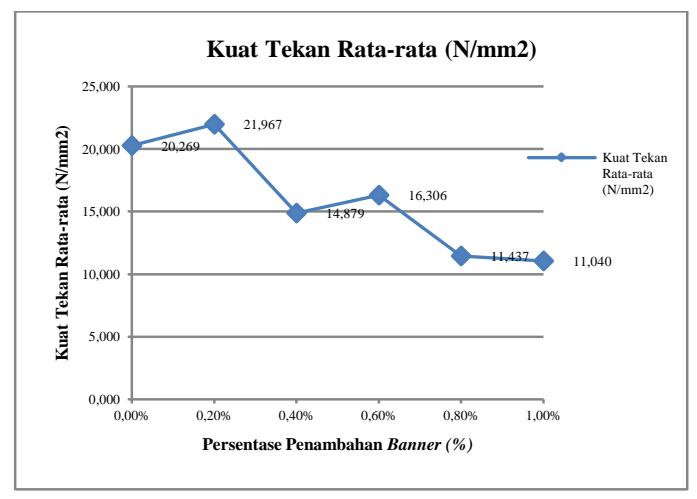
Gambar 6. Grafik
Pengaruh Penambahan terhadap Kuat Tekan Beton. 




Gambar 7. Diagram Batang Kuat Tekan Beton.

Berdasarkan bacaan diagram batang diatas maka dapat diketahui nilai optimal penambahan potongan limbah banner yaitu $0,20 \%$ dengan nilai maksimal kuat tekan yang dihasilkan adalah 21,967 N/mm². Penambahan optimal berada pada persentase $0,20 \%$, dengan demikian maka dapat disimpulkan bahwa beton dengan penambahan potongan limbah banner memiliki kuat tekan terbaik dibanding dengan variasi persentase $0,40 \%, 0,60 \%, 0,80 \%$ dan $1,00 \%$.

\section{Kuat Lentur}

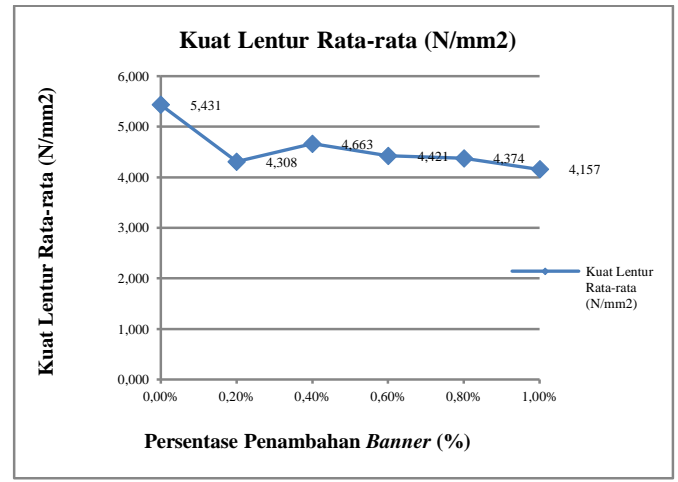

Gambar 8. Grafik

Pengaruh Penambahan terhadap Kuat Lentur Beton.

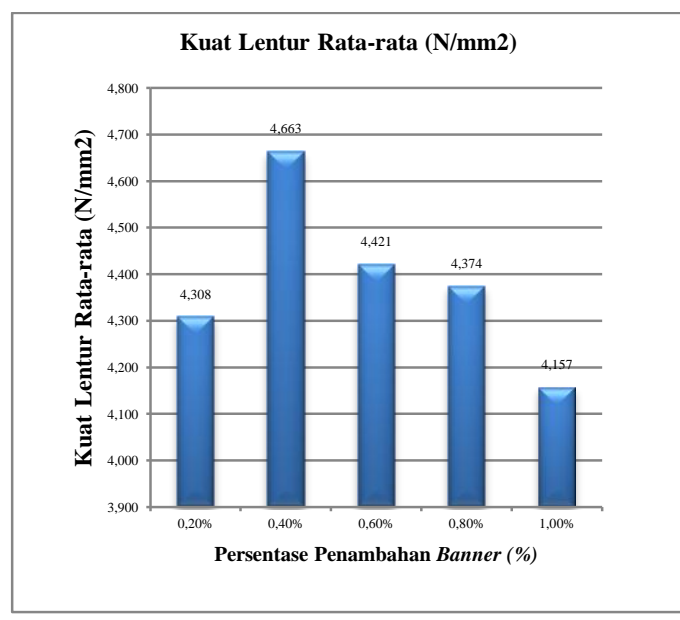

Gambar 9. Grafik Pengaruh Penambahan terhadap Kuat Lentur Beton.

Berdasarkan bacaan diagram batang diatas maka dapat diketahui nilai optimal penambahan potongan limbah banner yaitu 0,40\% dengan nilai maksimal kuat lentur yang dihasilkan adalah 4,663 N/mm². Penambahan optimal berada pada 
persentase $0,40 \%$, dengan demikian maka dapat disimpulkan bahwa beton dengan penambahan potongan limbah banner memiliki kuat lentur terbaik pada persentase $0,40 \%$ dibanding dengan variasi persentase yang lain. Yaitu persentase $0,20 \%, 0,60 \%, 0,80 \%$ dan $1,00 \%$.

Beberapa hal yang mempengaruhi adanya penurunan nilai kuat tekan dan kuat lentur beton adalah permukaan banner yang licin sehingga tidak terjadi rekatan yang baik antar agregat. Potongan dan bentuk serat yang digunakan berupa bidang sehingga membentuk spesimenspesimen pada beton yang selanjutnya menyebabkan adanya rongga-rongga udara didalam beton. Hal ini tidak sependapat dengan penelitian yang telah dilakukan oleh Saifudin (2015), dimana serat yang digunakan memiliki bentuk serabut panjang dengan diameter yang kecil sehingga serat memiliki nilai rasio yang besar. Penggunaan serat dengan bentuk serabut tidak akan mengganggu lekatan antar agregat dalam beton.
Sehingga akan didapat beton dengan kuat tekan dan kuat lentur yang baik.

Dalam penelitian ini semakin besar persentase penambahan, semakin kecil nilai slump yang dihasilkan. Sehingga nilai workability beton akan menurun atau sulit dipadatkan. Hal ini sependapat dengan penelitian yang dilakukan oleh Dachlan (2011), dalam penelitiannya disebutkan semakin banyak penambahan serat yang dilakukan menyebabkan balling dan kelecakan beton menurun. Sehingga beton sulit untuk dikerjakan. Akibat pengerjaan yang kurang maksimal menyebabkan turunnya kekuatan beton.

Bahan dasar penyusun banner adalah polyvinyl clorida dan nilon. Sehingga dalam adukan beton terjadi agresifitas asam dimana banner memiliki kandungan klorida dengan $\mathrm{Ph}$ larut dalam air sebesar 4,6 - 6,0 yang bersifat sangat asam, sedangkan semen merupakan senyawa basa dengan $\mathrm{Ph} \mathrm{11,8} \mathrm{-} \mathrm{18.} \mathrm{Hal} \mathrm{ini} \mathrm{sesuai}$ dengan pendapat Basuki (2012). 
Agresifitas asam yang terjadi akibat adanya kandungan asam yang terlalu tinggi pada adukan beton. Dimana semen merupakan alumina tinggi (high alumina cement concrete) yang bersifat sangat basa. Sehingga kinerja semen sebagai bahan perekat dalam campuran beton akan menurun. Penurunan kinerja semen dapat berakibat pada penurunan performa dan kekuatan beton. Maka semakin banyak serat yang ditambahkan akan semakin tinggi kandungan asam dalam adukan beton. Akibatnya akan terjadi penurunan terhadap kuat tekan dan kuat lentur pada beton.

\section{SIMPULAN DAN SARAN}

\section{Simpulan}

Berdasarkan hasil analisis data dan pembahasan dapat diambil simpulan sebagai berikut:

1. Terdapat pengaruh sedang namun bersifat negatif pada variasi persentase penambahan potongan limbah banner terhadap berat jenis beton, dimana semakin besar persentase penambahan semakin kecil nilai berat jenis beton.
2. Terdapat pengaruh kuat namun bersifat negatif pada variasi persentase penambahan potongan limbah banner terhadap kuat tekan beton, dimana senakin besar persentase penambahan semakin kecil kuat tekan beton yang dihasilkan.

3. Terdapat pengaruh sedang yang bersifat yang negatif variasi pada persentase penambahan potongan limbah banner terhadap kuat lentur beton, dimana semakin besar persentase penamnbahan semakin kecil kuat lentur beton yang dihasilkan.

4. Terdapat nilai optimal penambahan banner terhadap kuat tekan maksimal beton yang dihasilkan yaitu kuat tekan berada pada persentase optimal $0,20 \%$ dengan kuat tekan maksimal 21,967 $\mathrm{N} / \mathrm{mm}^{2}$.

5. Terdapat nilai optimal penambahan banner terhadap kuat lentur maksimal beton yang dhasilkan yaitu kuat lentur berada pada 
persentase optimal $0,40 \%$ dengan kuat lentur maksimal 4,663 N/mm²

\section{Saran}

Berdasarkan simpulan dan implikasi hasil penelitian, maka dapat dikemukakan saran sebagai berikut:

1. Perlu dilakukan penelitian tentang kandungan bahan kimia pada banner dan reaksi kimia yang ditimbulkan jika banner digunakan sebagai serat dalam adukan beton.

2. Perlu adanya penelitian lebih lanjut tentang penambahan admixture (bahan tambah) pada beton dengan menggunakan serat banner.

3. Perlu adanya penelitian lebih lanjut tentang nilai rasio atau ukuran potongan banner untuk menghasilkan beton dengan kuat tekan dan kuat lentur yang baik.

4. Perlu adanya penelitian lebih lanjut bentuk potongan banner untuk menghasilkan beton serat dengan kuat tekan dan kuat lentur yang baik.

5. Perlu adanya penelitian tentang metode pencampuran serat potongan limbah banner yang tepat pada adukan beton agar tidak terjadi balling dan adukan yang dihasilkan homogen.

6. Perlu adanya penelitian tentang pemanfaatan limbah banner untuk adukan beton jika diambil serat nilonnya saja untuk menghasilkan beton dengan kuat tekan dan kuat lentur yang lebih baik.

7. Perlu adanya perhatian dalam penggunaan alat uji, yaitu kapasitas alat uji. Alat uji yang digunakan pada penelitian ini adalah Universal Testing Machine (UTM) dengan kapasitas beban maksimal $50 \mathrm{KN}$. Sehingga dapat digunakan untuk pengujian lentur beton. Tetapi alat uji ini tidak dapat digunakan untuk uji kuat tekan beton. Oleh karena itu pengujian tekan dilakukan dengan alat Compression Testing Machine (CTM).

\section{DAFTAR PUSTAKA}

Anonim. (2010). Laju Pertumbuhan Penduduk Indonesia. Diperoleh 23 November 2015 dari 
http://bps.go.id/linkTabelStatis/ view/id/1268/

Asroni, A. (2010). Balok dan Pelat Beton Bertulang. Yogyakarta: Graha Ilmu.

Basuki, Achmad. (2012). Serangan Kimia pada Beton. Diperoleh 11 Mei 2016 dari http://sipil.ft.uns.ac.id/index.ph p?option $=$ com_content $\&$ task $=\mathrm{v}$ $\underline{\text { iew \&id=209\&Itemid=1 }}$

Dachlan, Tatang (2011). Jurnal : Perkerasan Jalan Beton Semen dengan Serat Polimer Sintetis. Jurnal. Bandung: Pusat Litbang Jalan dan Jembatan.

Mulyono, Tri. (2005). Teknologi Beton. Yogyakarta: Andi.

Nugraha, P \& Antoni. (2007). Teknologi Beton: Material, Pembuatan, ke Beton Kinerja Tinggi. Yogyakarta: Andi.

Pine, S.H., Hendrickson, J.B., Cram, D.J., \& Hammond, G.S. (1988). Kimia Organik 2. Bandung: ITB Bandung.

Saifudin, Ahmad. (2015). Pengaruh Dosis, Aspek Rasio, dan Distribusi Serat terhadap Kuat Lentur dan Kuat Tarik Belah Beton Berserat Baja. Skripsi.
Surakarta: Teknik Sipil Universita Sebelas Maret.

Sarjono, H., Julianita, W. (2011). SPSS vs LISREL Sebuah pengantar Aplikasi untuk Riset. Jakarta: Salemba Empat.

SNI 03-2834-2002. Tata Cara Pembuatan Rencana Campuran Beton Normal.

SNI 03-1972-1990. Metode Pengujian Slump Beton

SNI 03-1974-1990. Metode Pengujian Kuat Tekan Beton.

SNI 03-4254-1996. Metode Pengujian Kuat Lentur Beton dengan Balok Uji Sederhana yang Dibebani Terpusat Langsung.

Stevens dan Malcolm. (2001). Kimia Polimer. Jakarta: Prada Paramita.

Sugiyono. (2015). Statistik untuk Penelitian. Bandung: Alfabeta.

Tjokrodimuljo, K. (2004). Teknologi Beton. Jurusan Teknik Sipil, Fakultas Teknik, Universitas Gajah Mada. Yogyakarta: UGM.

Winardi,. (1992). Promosi dan Reklame. Bandung: Mandar Maju. 